Wiktor Gardocki

DOI 10.15290/sw.2019.19.02

Uniwersytet w Białymstoku

Katedra Badań Porównawczych i Edytorstwa

Zakład Badań Filologicznych nad Cenzurą PRL

tel.: +487457514

e-mail: w.gardocki@uwb.edu.pl

ORCID ID: https://orcid.org/0000-0002-3245-0650

\title{
Cenzurowanie wątków rosyjskich w polskiej poezji lat 80 . XX wieku
}

Słowa kluczowe: cenzura, poezja, GUKPPiW, lata 80., Polska

\section{Wprowadzenie}

Na przestrzeni lat 80. XX wieku kilkukrotnie zmieniały się uwarunkowania prawne dotyczące cenzury prewencyjnej. Do lipca 1981 r. w mocy pozostawał jeszcze dekret o utworzeniu GUKPPiW z 5 lipca 1946 r. ${ }^{1} \mathrm{~W}$ latach 1980-1981 miały miejsce społeczne protesty, które podobnie jak w drugiej połowie lat 40., 1956 czy 1970 r. - ujawniły słabość ówczesnej władzy. Jak pisze Zbigniew Romek, by nie dopuścić do eskalacji napiętej sytuacji w kraju, rezygnowano z części obostrzeń:

[...] partia [...] i cenzura stosowały zasadę „wentyla bezpieczeństwa”, dopuszczając do bardziej niż zazwyczaj śmiałych wypowiedzi. W tych wypadkach decyzje o złagodzeniu cenzury były posunięciami wymuszonymi niekorzystnymi okolicznościami, dlatego można było pisać i mówić więcej²

1 Wraz z dekretem uzupełniającym z 11 listopada 1953 r.), a także późniejsze uzupełnienie tych przepisów, to znaczy Rozporzadzenie Prezesa Rady Ministrów z dnia 22 kwietnia 1975 r. w sprawie zakresu i trybu sprawowania nadzoru $i$ kontroli przez Gtówny Urzad Kontroli Prasy, Publikacji i Widowisk.

2 Z. Romek, System cenzury PRL, w: T. Strzyżewski, Wielka ksiega cenzury PRL $w$ dokumentach, Warszawa 2015, s. 17. 
Potwierdzają to statystyki ingerencji z 1980 r. - od stycznia do lipca utrzymywały się one na podobnym poziomie 700-800 miesięcznie; w sierpniu zaczęły spadać, lecz ta tendencja utrzymała się zaledwie do listopada, gdy odnotowano 430 ingerencji; w grudniu znów zaczęto cenzurować i zatrzymywać więcej tekstów [Krajewski 2004, 497].

Właśnie między innymi z powodu społecznych protestów oraz ustaleń osiągniętych podczas porozumień sierpniowych z 1980 r. - prowadzono w Polsce dyskusję nad nową ustawą o cenzurze - w efekcie powstały jej dwa projekty: rządowy i społeczny. Jak pisze Piotr Perkowski, drugi z nich pod koniec 1980 r. trafil do Sejmu i tam, omówiony w jednej z podkomisji, został zmieniony „na niekorzyść cenzury” ${ }^{3}$.

Ostatecznie 31 lipca $1981 \mathrm{r}$. wprowadzono w Polsce nową, teoretycznie łagodniejszą ustawę o cenzurze. Weszła ona w życie dwa miesiące później, 1 października. Nazwę instytucji zmieniono na Główny Urząd Kontroli Publikacji i Widowisk; od tej pory jego decyzje miały być bardziej przejrzyste. Zniesiono też zapisy personalne. Biblioteki mogły sprowadzać i gromadzić publikacje zagraniczne, wcześniej w Polsce zakazane. Jeśli chodzi o cenzurę prewencyjną, „sukcesem było wymuszenie na komunistycznej władzy zwolnienia z obowiązku kontroli przez cenzurę: przemówień posłów i radnych, orzeczeń sądów, druków przeznaczonych do użytku służbowego, publikacji naukowych i dydaktycznych, druków na prawach rękopisu (nakład do 100 egz.) [Romek 2015, 17]. Pojawiły się jednak także ograniczenia. Stanisław Momot zwracał uwagę na art. 2 pkt 7. Ustawy: „(..) nie można (...) ujawnić bez zgody zainteresowanych stron wiadomości z postępowania przygotowawczego oraz rozpowszechniać wiadomości z rozprawy sądowej prowadzonej z wyłączeniem jawności”, po czym konstatuje: „Co zatem można pisać? (...) praktycznie nic" [Momot 1982, 47-49].

Artykuł 2., jeden z najważniejszych w ustawie, stał się przedmiotem dyskusji dotyczących zakresu działalności GUKPiW, zwłaszcza z powodu sformułowań, którymi osoby kontrolujące teksty, mogły uzasadniać praktycznie każdą negatywną decyzję dotyczącą publikacji ${ }^{4}$. Z powodu ogłoszenia w Polsce stanu wojennego, nowa ustawa obowiązywała zaledwie do 12 grudnia 1981 r.; wprowadzony wówczas dekret:

3 P. Perkowski, Działalność Gtównego Urzędu Kontroli Prasy, Publikacji i Widowisk $w$ latach siedemdziesiatych [niepublikowana praca doktorska napisana pod kierunkiem dr hab. Barbary Okoniewskiej, prof. UG], Gdańsk 2005, s. 25-26.

4 Ustawa z dnia 31 lipca 1981 r. o kontroli publikacji i widowisk, Dz.U. nr 20 z 1981, poz. 99 . 
[...] w art. 17 rozszerzył zakres publikacji poddanych cenzurze, jak i podstawy ingerencji cenzorskich przez wprowadzenie postanowienia, wg którego można odmówić zezwolenia na rozpowszechnianie publikacji, jeśli zagrażałoby to interesom bezpieczeństwa lub obronności państwa ${ }^{5}$.

Jeszcze 13 grudnia dyrektorzy Okręgowych Urzędów Kontroli Publikacji i Widowisk otrzymali od Stanisława Kosickiego dokument, w którym określono zasady postępowania w okresie obowiązywania stanu wojennego ${ }^{6}$.

Przepisy zatem zaostrzono. W realiach stanu wojennego powrócono do skrupulatnego cenzurowania. Początkowo, gdy zawieszono działalność większości tytułów prasowych, Główny Urząd nie miał wiele pracy. Natomiast, od początku 1982 r., kiedy stopniowo czasopismom i oficynom wydawano zgody na działalność wydawniczą, tekstów do kontroli przybywało. Tymczasowo przywrócono „zapisy” na konkretne dzieła literackie ${ }^{7}$.

Przy Mysiej zwrócono również uwagę na niejasność przepisów z 31 lipca $1981 \mathrm{r}$. Liczono się z tym, że w nieodległej przyszłości stan wojenny zostanie zniesiony i powrócą problemy z cenzurą prewencyjną, których doświadczono między 1 października a 12 grudnia $1981 \mathrm{r}$.

Kolejna zmiana uwarunkowań prawnych miała miejsce już po zakończeniu stanu wojennego. 28 lipca $1983 \mathrm{r}$. wprowadzono nowelizacje ustawy o cenzurze. To, w jaki sposób interpretowano jej zapisy, a właściwie nimi manipulowano, pokazuje Zofia Radzikowska na przykładzie art. 2 pkt 1, 6.2 oraz 3 ustawy o cenzurze:

W momencie znoszenia stanu wojennego zapowiedziano zmianę ustawy o cenzurze i zmiana taka została przeprowadzona (...) Polegała ona na wprowadzeniu na stałe do ustawy (...) przepisów art. 17 pkt 1 i 4 dekretu o stanie wojennym, a w jednym punkcie poszła nawet dalej. W wyniku tej zmiany do wspomnianego art. 2 pkt 1 wprowadzono wyrażenie:

albo zagrażać bezpieczeństwu państwa [to i kolejne podkr. - Z. Radzikowska],

do pkt 5:

albo w inny sposób zagrażać obronności państwa, a do pkt 6 :

a także rozpowszechniać treści oczywiście stanowiące przestępstwo ${ }^{8}$.

5 Z. Radzikowska, Z historii walki o wolność słowa w Polsce. Cenzura PRL w latach 1981-1987, Kraków 1990, s. 8.

6 AAN, GUKPPiW, sygn. 2014 (406/1), k. 6.

7 AAN, GUKPPiW, sygn. $1704(334 / 24)$, k. 178.

8 Z. Radzikowska, dz. cyt., s. 9-30. 
Przepisy te obowiązywały do 29 maja 1989 r. Wówczas po raz kolejny znowelizowano ustawę i, jak pisze Kamila Kamińska, „okres po wejściu jej w życie (6 czerwca 1989 r.) nie znajduje odpowiednika pod względem spadku liczby ingerencji w dziejach cenzury PRL" [Kamińska 2014, 118]. Z art. 2., ust. 1, ustawy skreślono wówczas: „(...) albo zagrażać bezpieczeństwu państwa”, w ust. 5: „(...) albo w inny sposób zagrażać obronności państwa”, a w ust. 6.: „(..) a także rozpowszechniać treści oczywiście stanowiące przestępstwo" ${ }^{9}$. Zasady cenzurowania tekstów stały się znacznie bardziej liberalne.

Zmiany $\mathrm{w}$ przepisach znajdowały odzwierciedlenie $\mathrm{w}$ podejściu urzędników do kontrolowanych treści, chociaż należy przyznać, że na przestrzeni lat cenzurowali oni podobne tematy. Ingerencji w utworach poetyckich dokonywano najczęściej z powodu szeroko pojmowanej tematyki politycznej wiersz, w którym dostrzeżono jakiekolwiek nawiązania (dosłowne, metaforyczne, alegoryczne) do „sytuacji bieżącej”, nie był dopuszczany do publikacji. Ewentualnie wykreślano fragment wskazujący na aktualny kontekst. Cenzor, interpretując utwór, zawsze odnosił go do sytuacji społeczno-politycznej, gospodarczej, kulturalnej czy uwarunkowań historycznych ${ }^{10}$. Szczególnie widać to w przypadku wierszy, w których skreślono jedynie pojedyncze słowa lub krótkie fragmenty - wycięte, newralgiczne ustępy zawsze dotyczą wymienionych obszarów. Inny wymiar miały z kolei ingerencje dokonywane zgodnie z ,zapisem” - w tej sytuacji nie dopuszczano do publikacji utworu, o czymkolwiek traktował.

Cenzura zatrzymywała więc teksty ze względu na tematykę: zarówno utwory nawiązujące do kwestii politycznych (totalitaryzm, uwięzienie, powstania narodowe, druga wojna światowa i okupacja), jak i te o uniwersalnej wymowie (zło, dobro, Bóg), które jednak również można odnosić do wymienionych motywów. Stąd, w materiałach GUKPiW w przeważającej części znajdują się wiersze, które można odczytywać jako polityczne. Cenzurowanie utworów poetyckich, zatrzymywanie ich fragmentów bądź kompletnych wersji - mogło wpłynąć na sposób postrzegania ówczesnej poezji, właśnie jako zaangażowanej, politycznej, jednowymiarowej. Rzeczywiście, w przypadku niektórych utworów, trudno mówić o innej interpretacji - jednak uogólnianie i odnoszenie tej opinii do niemal całej polskiej poezji lat 80 . jest dużym uproszczeniem [Matuszewski 1995, 194-195; Czapliński, Śliwiński 2000, 94].

9 Dz.U. z 1989 r. Nr 34 poz. 186.

10 Jak stwierdził w jednym z wywiadów Jacek Woźniakowski: „[cenzorzy] we wszystkim widzieli aluzje do Polski Ludowej, co chwilami bywało zabawne" - J. Woźniakowski, My i oni, rozm. T. Walas, „Dekada Literacka” 1996, nr 1, s. 3. 


\section{Przykłady}

O cenzurowaniu literatury w latach 1945-1989 pisano już wielokrotnie ${ }^{11}$, jednak znacznie mniej miejsca poświęcano aspektowi kontroli tekstów w latach $80 \mathrm{XX}$ wieku ${ }^{12}$. Wśród publikacji można wyróżnić również te, w których

11 Na przykład: M. Fik, Kultura polska po Jatcie. Kronika lat 1944-1981, Warszawa 1989; S.A. Kondek, Wladza $i$ wydawcy: polityczne uwarunkowania produkcji ksiażek w Polsce w latach 1944-1949, Warszawa 1993; Dokumenty do dziejów PRL, opr. D. Nałęcz, Warszawa 1994; A. Paczkowski, Cenzura 1946-1949: statystyka działalności, „Zeszyty Historyczne" 1996, z. 116, s. 22-57; S.A. Kondek, Papierowa rewolucja. Oficjalny obieg ksiażek w Polsce w latach 1948-1955, Warszawa 1999; J. Hobot, Gra z cenzura w poezji Nowej Fali (1968-1976), Kraków 2000; A. Pawlicki, Kompletna szarość. Cenzura w latach 196-1972. Instytucja i ludzie, Warszawa 2001; J. Bates, Cenzura w epoce Stalinowskiej, „Teksty Drugie" 2001, nr 1-2; P. Perkowski, Działalność Gtównego Urzędu Kontroli Prasy, Publikacji $i$ Widowisk w latach siedemdziesiatych [niepublikowana praca doktorska], Gdańsk 2005; A. Bikont, J. Szczęsna, Lawina i kamienie. Pisarze wobec komunizmu, Warszawa 2006; Niewygodne dla wladzy: ograniczanie wolności słowa na ziemiach polskich w XIX i XX wieku, red. D. Degen, J. Gzella, Toruń 2009; K. Budrowska, Literatura i pisarze wobec Cenzury PRL 1948-1958, Białystok 2009; Z. Romek, Cenzura a nauka historyczna w Polsce 1944-1970, Warszawa 2010; Przeskoczyć te studnie strachu. Autor i dzieto a cenzura PRL, red. E. Skorupa, Kraków 2010; „Lancetem, a nie maczuga”. Cenzura wobec literatury i jej twórców w latach 1945-1968, red. K. Budrowska, M. Woźniak-Łabieniec, Warszawa 2012; Nie po myśli wtadzy. Studia nad cenzura i zakresem wolności słowa na ziemiach polskich od wieku XIX do czasów wspótczesnych, red. D. Degen, M. Żynda, Toruń 2012; M. Woźniak-Łabieniec, Obecny nieobecny: krajowa recepcja Czesława Miłosza w krytyce literackiej lat pięćdziesiątych w świetle dokumentów cenzury, Łódź 2012; Literatura $w$ granicach prawa, red. K. Budrowska, E. Dąbrowicz, M. Lul, Warszawa 2013; „Nie należy dopuszczać do publikacji”: cenzura w PRL: zbiór studiów, red. G. Gzella, J. Gzella, Toruń 2013; K. Budrowska, Zatrzymane przez cenzure. Inedita z połowy wieku XX, Warszawa 2013; Kariera pisarza w PRL-u, red. M. Budnik, K. Budrowska, E. Dąbrowicz, K. Kościewicz, Warszawa 2014; W. Gardocki, Wymiana idei i doświadczeń. Wspótpraca Gtównego Urzędu Kontroli Prasy, Publikacji i Widowisk z Gtawlitem, „Wschodni Rocznik Humanistyczny" 2014, t. X, s. 41-50; Zakazane i niewygodne: ograniczanie wolności słowa od XIX do XXI wieku, red. D. Degen, G. Gzella, J. Gzella, Toruń 2015.

12 „1984." Literatura i kultura schylkowego PRL-u, red. K. Budrowska, W. Gardocki, E. Jurkowska, Warszawa 2015; J. Ladorucki, O próbach negacji cenzury instytucjonalnej $i$ egzystencjalnej na przykładzie drugoobiegowej działalności tódzkiego „Pulsu” $i$ krakowskiego „bruLionu”. Podobieństwa i różnice w strategii działania obydwu periodyków, [w:] Niewygodne dla wladzy. Ograniczanie wolności stowa na ziemiach polskich w XIX i XX wieku, red. D. Degen, J. Gzella, Toruń 2010, s. 435-454; Z. Kropidłowski, Ingerencja cenzury w dzialalności Gdańskiego Dwutygodnika „Gwiazda Morza” w latach 1983-1989, [w:] tamże, s. 455-474; M. Świstak, Niepolityczne tabu PRL, czyli o cenzurze obyczajowej lat 80., [w:] Przeskoczyć te studnię strachu: autor i dzieło a cenzura PRL, red. E. Skorupa, Kraków 2010, s. 115-131; J. Wojsław, Miejsce cenzury w ocenach aparatu partyjnego w okresie politycznej konfrontacji lat 1980-1981, [w:] Nie należy dopuszczać do publikacji. Cenzura w PRL, red. G. Gzella, J. Gzella, Toruń 2013, s. 195-216; K. Tułać, Niezależna polska prasa mtodzieżowa lat 80. XX wieku. Gtosy o cenzurze, [w:] Zakazane i niewygodne. Ograniczanie wolności stowa w XIX i XX wieku, red. D. Degen, G. Gzella, J. Gzella, Toruń 2015, s. 215-232; K. Kamińska, Cenzura instytucjonalna w przededniu okragłego stotu - analiza tematyczna i statystyczna ingerencji, [w:] tamże, s. 233-244; W. Gardocki, Dzie- 
podjęto temat cenzurowania tematyki rosyjskiej ${ }^{13}$. Niniejszy artykuł stanowi próbę opisania

W latach 1982-1984 ingerowano w pięć wierszy Jana Bolesława Ożoga, cztery z nich miały ukazać się w tomie $\mathrm{Na}$ ucho łopianowi, jeden zaś w czasopiśmie „Tu i Teraz”. Właściwie we wszystkich utworach można dostrzec wątki „rosyjskie”. W całości postanowiono zatrzymać wiersz pod tytułem Dokoła $^{14}$, poruszający kwestię niemożności odnalezienia własnego miejsca i wyrzeczenia się ojczyzny. Najwyraźniej jednak Wydawnictwo Literackie odwołało się od decyzji GUKPiW, ponieważ utwór ostatecznie znalazł się w książce, choć z drobnymi zmianami. W pierwotnej wersji pierwsza strofa brzmiała:

Dokoła zamula nas chytrość i gwałt.

Z bogów nas i mowy okradają.

Pola Azją nakrywają ${ }^{15}$.

W wydaniu książkowym opublikowano fragment w innej wersji:

Dokoła zamula nas chytrość i gwałt.

Z bogów nas i z mowy okradają.

Pola piekłem nakrywają ${ }^{16}$.

"Azja” nazbyt kojarzyłaby się z Rosją. Znaleziono dlań zatem swoisty synonim - „piekło". W takiej, zmienionej wersji utwór zyskał aprobatę urzędników GUKPiW.

Z kolei, z Oskarżenia ${ }^{17}$, kolejnego wiersza, który znalazł się w omawianym tomie, usunięto jeden wers:

\footnotetext{
je wydawnicze $i$ recepcja „Kapitana” Jana Józefa Szczepańskiego; Cenzurowanie poezji w latach 80. XX wieku, w: "Sztuka czytania między wierszami”. Cenzura w komunikacji literackiej w Polsce w latach 1965-1989, Warszawa 2016, s. 159-200.

13 Świat pod kontrola. Wybór materiałów z archiwum cenzury rosyjskiej w Warszawie, opr. M. Prussak, Warszawa 1994; P. Nowak, Cenzura w PRL jako nieefektywna kopia radzieckiej hybrydy leninowsko-stalinowskiej. Nowe spojrzenie na Główny Urzad Kontroli Prasy, Publikacji i Widowisk, w: Nie należy dopuszczać do publikacji. Cenzura w PRL, red. G. Gzella, J. Gzella, Toruń 2013, s. 39-52; K. Budrowska, Cenzurowanie tematyki rosyjskiej w literaturze pięknej w Polsce w l. 1948-1960, „Wschodni Rocznik Humanistyczny” 2014, tom X, s. 91-102.

14 J.B. Ożóg, Dokoła, „Fakty” 1982, nr 17, s. 9.

15 AAN, GUKPPiW, sygn. 1686 (334/6), k. 50.

16 J.B. Ożóg, Dokoła, [w:] Na ucho łopianowi, Kraków 1982, s. 7.

17 Prwdr.: J.B. Ożóg, Oskarżenie, [w:] Na ucho topianowi, Kraków 1982.
} 
Wystarczyło mu, że chwalił kino w mieście, rosyjskie sztandary, pijane kawiarnie i koncerty na cztery wiaderka ${ }^{18}$

Ingerencję, zgodnie z obowiązującymi przepisami, oznaczono w książce wielokropkiem.

W wierszu Równość ${ }^{19}$ dokonano natomiast zamiany. Dwuwiersz: „Dlatego do łagrów ciągną jak Tatary" 20 zastąpiono - być może po konsultacji z Ożogiem - mało zrozumiałą frazą: „Dlatego na rozwałkę / lub pod sieci ciągną / jak Tatary" ${ }^{21}$. W książce w żaden sposób nie oznaczono tej ingerencji. W pozostałych ocenzurowanych wierszach Ożoga można natomiast dostrzec linię przerywaną.

W całości usunięto inny tekst Ożoga, Żółkiewskiego ${ }^{22}$, przekazany do urzędu w 1984 r. przez redakcję „Tu i Teraz”. W tym wierszu również pojawia się tematyka „rosyjska”, co rzecz jasna nie uszło uwadze cenzorów. Zdecydowanie najbardziej wyrazista, choć i patetyczna, jest puenta utworu:

Pamiętajcie, rozbici na włoskie orzechy -
powiewały z Kremla biało-czerwone sztandary,
w cerkwiach złotych popi klękali pokornie
z ikonami w rękach drgających od lęku i trwogi
i chorągwie polskie pasły tłuste konie
nad brzegami wód zielonej Moskwy!

Wiersza nie próbowano opublikować w okresie stanu wojennego, jednak w swej wymowie niewątpliwie nawiązuje do ocenzurowanych utworów Ożoga z 1982 r. W tym wypadku kontekst jest jednak szerszy, ponieważ poeta przypomina historyczną postać Stefana Żółkiewskiego oraz wojnę polsko-rosyjską z XVII wieku. Przeszłość, choć odległa była zdaniem urzędników GUKPiW „niewygodna”. Nie można było przedstawiać Rosji w negatywnym świetle, w obliczu klęski zadanej przez Polaków.

To, jak bardzo cenzorzy dbali o szczegóły, pokazuje inna, tym razem częściowa ingerencja, dotycząca wiersza Dzieciństwo 1940 Jerzego Ficowskiego $^{24}$. Usunięto podkreślony fragment:

18 AAN, GUKPPiW, sygn. 1686 (334/6), k. 50.

19 Prwdr.: J.B. Ożóg, Równość, [w:] Na ucho topianowi, Kraków 1982.

20 AAN, GUKPPiW, sygn. 1686 (334/6), k. 50-51.

21 J.B. Ożóg, Równość, [w:] Na ucho topianowi, dz. cyt., s. 28.

22 Prwdr.: J.B. Ożóg, Żótkiewski, „Życie Literackie” 1989, nr 1, s. 4.

23 AAN, GUKPPiW, sygn. 1769 (354/5), k. 90.

24 Prwdr.: J. Ficowski, Dzieciństwo, [w:] tegoż, Errata. Wiersze, Londyn 1981. 


\begin{abstract}
więc przez lunety sopli
wyglądałyśmy

czy zza wszystkich sybirów

nie leci po nas Pan Bóg

na tej białej wronie ${ }^{25}$
\end{abstract}

Na liście najważniejszych motywów, których odnalezienie było zadaniem urzędników cenzury, bez wątpienia znajdowały się te związane ze Związkiem Radzieckim. Jakiekolwiek nawiązanie do wywózek na wschód czy zsyłek na Syberię - traktowane jako nośnik ukrytego przesłania - było bezwzględnie usuwane. Sugerując się tymi wytycznymi, ingerowano też w inny utwór Ficowskiego, Erratę $e^{26}$, która ostatecznie ukazała się we fragmentach.

W 1987 r. urzędnicy zatrzymali wiersz nieżyjącego już od ponad trzydziestu lat Jana Lechonia (1899-1956), przekazany przez redakcje „Przeglądu Tygodniowego". Utwór pod tytułem Arcybiskup Cieplak odczytano prawdopodobnie jako aluzję do sytuacji społeczno-politycznej w Polsce drugiej połowy lat 80. i odniesienie do stosunków polsko-radzieckich. Wiersz miał być dodatkowo opatrzony notą autorstwa Romana Lotha. Tej również nie dopuszczono do druku:

Jan Cieplak (...). Był gorliwym krzewicielem polskości i wiary w środowiskach polskich na ziemiach Rosji, aż po Sachalin. Aresztowany w czerwcu 1922 roku pod zarzutem działalności antypaństwowej, był sądzony w procesie moskiewskim (21-25 marca 1923) wraz z czternastoma księżmi i został skazany na karę śmierci. Z godnością i męstwem, ,jak Książę z Calderona”, przyjął przeznaczone mu męczeństwo za wiarę 27 .

Arcybiskup skazany przez Rosjan na karę śmierci - to mogło zostać odebrane jako prowokacja. Przede wszystkim jednak, w GUKPiW pamiętano o „zapisie" na Cieplaka sprzed kilku lat²8. Nie obowiązywał on już wprawdzie w drugiej połowie lat 80., jednak wciąż - wiedząc, jak newralgiczny jest temat - brano go pod uwagę. Wiersz, z komentarzem Lotha, ukazał się dwa lata później na łamach „Przeglądu Katolickiego” 29.

25 AAN, GUKPPiW, sygn. 1684 (334/4), k. 80.

26 Prwdr.: J. Ficowski, Errata, [w:] tegoż, Errata. Wiersze, Londyn 1981.

27 AAN, GUKPPiW, sygn. 2060 (416/12), k. 98.

28 Zapis znajduje się w „Książce zapisów i zaleceń” z 1975 r., t. 1: „należy eliminować informacje o arcybiskupie Janie Cieplaku (...) Należy eliminować wszelkie informacje dotyczące zmarłego w 1925 roku arcybp. Jana Cieplaka" - zob. AAN, GUKPPiW, sygn. 1304, k. 29 i 35 - za udostępnienie tej notatki dziękuję Marii Kotowskiej-Kachel.

29 J. Lechoń, Arcybiskup Cieplak, „Przegląd Katolicki” 1989, nr 52/53, s. 9. 
Jedną z najważniejszych kwestii z radzieckim wątkiem w tle było zamordowanie polskich oficerów w Katyniu. Jeszcze w drugiej połowie lat 80 . w Polsce propagowano tezę, że odpowiedzialni za to są żołnierze niemieccy. W archiwaliach Głównego Urzędu zachowała się notka informacyjna, sporządzona 19 marca 1980 r., zawierająca wskazówki, w jaki sposób kwestię tę postrzegać:

[...] Wszelkie publikacje nawiązujące do tych wydarzeń, zbieżne w swej treści i wymowie z wyżej przedstawionymi faktami i ustaleniami, można zwalniać. Eliminować natomiast należy swoistą kontynuację prowokacji propagandy hitlerowskiej oraz b. rządu londyńskiego, t.j. przypisywanie odpowiedzialności za tę zbrodnię organom radzieckim. Takie próby mają najczęściej charakter zakamuflowany m.in. poprzez tendencyjne manipulowanie datami i nazwami geograficznymi oraz nazwami, w których b. oficerowie i żołnierze kiedyś pracowali itp..$^{30}$

Założenia wyrażone w powyższej notce przetrwały do drugiej połowy lat 80 . (innej, późniejszej wersji tego dokumentu dotychczas nie udało się odnaleźć).

W wierszu Czarny optatek ${ }^{31}$ Tadeusz Urgacz poruszył temat Katynia w nieodpowiedni sposób, ponieważ treść jednoznacznie wskazywała na narodowość winowajców („widmo cerkiewki przez kolczaste/ druty”). Decyzją GUKPiW, w grudniu 1987 r., wiersz zatrzymano. Oto fragmenty tego wiersza:

$$
\begin{aligned}
& \text { Czarnym opłatkiem się łamali } \\
& \text { w noc wigilijną. Dymił mróz } \\
& \text { i gwiazda gasła nad Katyniem } \\
& \text { jakby na zawsze gasła już. } \\
& {[\ldots]} \\
& \text { Widmo cerkiewki przez kolczaste } \\
& \text { druty ze śniegiem do nich szło } \\
& \text { jakby kościółek podhalański } \\
& \text { z Panienką malowaną pstro }[. . .]^{32}
\end{aligned}
$$

„Kultura”, w której miał ukazać się Czarny opłatek, zgłosiła wówczas do wydania kilka innych wierszy Urgacza: Aniot '87, Chrystus się rodzi, Baruch, Baltazar, Mongot, Dostojewski, Psy Dżeka-żaden z nich nie wzbudził zastrzeżeń cenzora, wszystkie zostały opublikowane w pełnych wersjach ${ }^{33}$.

30 AAN, GUKPPiW, sygn. 1545 (293/28), k. 2-3.

31 Prwdr.: T. Urgacz, Czarny opłatek, „Kultura i Życie” 1989, nr 17, s. 2.

32 AAN, GUKPPiW, sygn. 2060 (416/12), k. 70.

33 T. Urgacz, Aniol '87, Chrystus sie rodzi, Baruch, Baltazar, Mongot, Dostojewski, Psy Dizeka, „Kultura” 1987, nr 51/52, s. 9. 


\section{Zakończenie}

Przykładów cenzurowania wątków rosyjskich w polskiej poezji lat 80 . jest oczywiście znacznie więcej. W niniejszym szkicu zaprezentowano jedynie najbardziej charakterystyczne aspekty i przykłady kontroli tekstów. Uważano, że wymowę utworu, zwłaszcza poetyckiego, można zmienić - usuwając choćby jeden wyraz (Dokoła Ożoga, Dzieciństwo Ficowskiego). Czyniono tak dość często, aby interpretacja nie była jednoznaczna. Zdarzały się jednak przypadki niedopuszczenia do druku całego utworu (Źótkiewski Ożoga) - na przykład w sytuacji, gdy poprawki sugerowane przez urzędników nie zostały zaakceptowane przez autora albo treść wiersza nie pozwalała na wprowadzenie ingerencji (wymowa wiersza, zdaniem GUKPPiW, była negatywna). Wątkiem, którego nie można pominąć przy temacie cenzurowania poezji, jest próba kontrolowania recepcji poszczególnych utworów - vide komentarz Romana Lotha do wiersza Jana Lechonia. W tym wypadku warto zwrócić uwagę na jeszcze jeden aspekt. Ingerencja ta miała prawdopodobnie związek z „,zapisem” na nazwisko arcybiskupa Cieplaka; „zapisem” z 1975 r., który $\mathrm{w}$ drugiej połowie lat 80 . teoretycznie nie miał prawa już obowiązywać.

Wszystkie przywołane w tekście wiersze są dzisiaj znane w kompletnych, nieocenzurowanych wersjach. Niestety, nie jest to regułą. Wiele utworów, z których cenzorzy wycięli fragmenty w latach 80. (lub wcześniej) nie zostało później wydanych. Wciąż odnajdywane są inedita. Warto podkreślić, że poezji - w przedostatniej dekadzie XX wieku - nie cenzurowano jedynie „doraźnie” (choć był to jeden ze sposobów), odrębnie rozpatrując każdy przypadek. Odwoływano się także do ,zapisów” personalnych na nazwisko lub konkretne dzieło literackie czy temat (na przykład zbrodnia w Katyniu). Obie te strategie można wyraźnie dostrzec na przykładzie cenzurowania wątków rosyjskich w literaturze polskiej lat 80 . XX wieku.

\section{Literatura}

„1984.” Literatura i kultura schytkowego PRL-u, red. K. Budrowska, W. Gardocki, E. Jurkowska, Warszawa 2015.

Bates J., Cenzura w epoce Stalinowskiej, „Teksty Drugie” 2001, nr 1-2.

Bikont A., Szczęsna J., Lawina i kamienie. Pisarze wobec komunizmu, Warszawa 2006.

Budrowska K., Cenzurowanie tematyki rosyjskiej w literaturze pięknej w Polsce w l. 1948-1960, „Wschodni Rocznik Humanistyczny” 2014, tom X.

Budrowska K., Literatura i pisarze wobec Cenzury PRL 1948-1958, Białystok 2009. 
Budrowska K., Zatrzymane przez cenzure. Inedita z połowy wieku XX, Warszawa 2013.

Czapliński P., Śliwiński P., Literatura polska 1976-1998: przewodnik po prozie i poezji, Kraków 2000.

Dokumenty do dziejów PRL, opr. D. Nałęcz, Warszawa 1994.

Ficowski J., Errata. Wiersze, Londyn 1981.

Fik M., Kultura polska po Jałcie. Kronika lat 1944-1981, Warszawa 1989.

Gardocki W., Dzieje wydawnicze i recepcja „Kapitana” Jana Józefa Szczepańskiego; Cenzurowanie poezji w latach 80. XX wieku, w: „Sztuka czytania między wierszami”. Cenzura w komunikacji literackiej w Polsce w latach 1965-1989, Warszawa 2016, s. 159-200.

Gardocki W., Wymiana idei i doświadczeń. Wspótpraca Gtównego Urzędu Kontroli Prasy, Publikacji $i$ Widowisk z Gławlitem, ,Wschodni Rocznik Humanistyczny" 2014, t. X, s. 41-50.

Hobot J., Gra z cenzura w poezji Nowej Fali (1968-1976), Kraków 2000.

Kamińska K., Cenzura instytucjonalna w przededniu okragtego stotu - analiza tematyczna $i$ statystyczna ingerencji, [w:] Zakazane $i$ niewygodne. Ograniczanie wolności słowa $w$ XIX $i$ XX wieku, red. D. Degen, G. Gzella, J. Gzella, Toruń 2015, s. 233-244.

Kamińska K., Koniec cenzury PRL, „Studia Medioznawcze” 2014, nr 3.

Kariera pisarza w PRL-u, red. M. Budnik, K. Budrowska, E. Dąbrowicz, K. Kościewicz, Warszawa 2014.

Kondek S.A., Papierowa rewolucja. Oficjalny obieg ksiązek w Polsce $w$ latach 1948-1955, Warszawa 1999.

Kondek S.A., Władza $i$ wydawcy: polityczne uwarunkowania produkcji książek w Polsce w latach 1944-1949, Warszawa 1993.

Krajewski A., Między wspótpraca a oporem. Twórcy kultury wobec systemu politycznego PRL (1975-1980), Warszawa 2004

Kropidłowski Z., Ingerencja cenzury w działalności Gdańskiego Dwutygodnika „Gwiazda Morza” w latach 1983-1989, [w:] tamże, s. 455-474.

Ladorucki J., O próbach negacji cenzury instytucjonalnej i egzystencjalnej na przykładzie drugoobiegowej działalności tódzkiego „Pulsu” i krakowskiego „,bruLionu”. Podobieństwa $i$ różnice $w$ strategii działania obydwu periodyków, [w:] Niewygodne dla władzy. Ograniczanie wolności słowa na ziemiach polskich w XIX i XX wieku, red. D. Degen, J. Gzella, Toruń 2010, s. 435-454.

Lechoń J., Arcybiskup Cieplak, „Przegląd Katolicki” 1989, nr 52/53.

Literatura w granicach prawa, red. K. Budrowska, E. Dąbrowicz, M. Lul, Warszawa 2013.

Matuszewski R., Literatura polska 1939-1991, Warszawa 1995, s. 194-195.

Momot S., Przepis potrzebny, zbędny czy szkodliwy?, „Problemy Praworządności: Organ Prokuratury Polskiej Rzeczypospolitej Ludowej” 1982, r. XXXIII, nr 2 . 
„Nie należy dopuszczać do publikacji”: cenzura w PRL: zbiór studiów, red. G. Gzella, J. Gzella, Toruń 2013.

Nie po myśli władzy. Studia nad cenzura $i$ zakresem wolności słowa na ziemiach polskich od wieku XIX do czasów wspótczesnych, red. D. Degen, M. Żynda, Toruń 2012.

Niewygodne dla władzy: ograniczanie wolności słowa na ziemiach polskich w XIX i XX wieku, red. D. Degen, J. Gzella, Toruń 2009.

Nowak P., Cenzura w PRL jako nieefektywna kopia radzieckiej hybrydy leninowsko-stalinowskiej. Nowe spojrzenie na Główny Urzad Kontroli Prasy, Publikacji $i$ Widowisk, w: Nie należy dopuszczać do publikacji. Cenzura w PRL, red. G. Gzella, J. Gzella, Toruń 2013

Ożóg J.B., Dokoła, „Fakty” 1982, nr 17.

Ożóg J.B., Na ucho topianowi, Kraków 1982.

Ożóg J.B., Żótkiewski, „Życie Literackie” 1989, nr 1.

Paczkowski A., Cenzura 1946-1949: statystyka działalności, „Zeszyty Historyczne” 1996 , z. 116 , s. $22-57$.

Pawlicki A., Kompletna szarość. Cenzura w latach 1965-1972. Instytucja i ludzie, Warszawa 2001.

Perkowski P., Działalność Gtównego Urzędu Kontroli Prasy, Publikacji i Widowisk w latach siedemdziesiatych [niepublikowana praca doktorska], Gdańsk 2005.

Przeskoczyć te studnie strachu. Autor i dzieto a cenzura PRL, red. E. Skorupa, Kraków 2010.

„Lancetem, a nie maczuga”. Cenzura wobec literatury i jej twórców w latach 1945-1968, red. K. Budrowska, M. Woźniak-Łabieniec, Warszawa 2012.

Radzikowska Z., Z historii walki o wolność stowa w Polsce. Cenzura PRL w latach 1981-1987, Kraków 1990.

Romek Z., Cenzura a nauka historyczna w Polsce 1944-1970, Warszawa 2010.

Romek Z., System cenzury PRL, w: T. Strzyżewski, Wielka ksiega cenzury PRL $w$ dokumentach, Warszawa 2015.

Świat pod kontrola. Wybór materiałów z archiwum cenzury rosyjskiej w Warszawie, opr. M. Prussak, Warszawa 1994.

Świstak M., Niepolityczne tabu PRL, czyli o cenzurze obyczajowej lat 80., [w:] Przeskoczyć te studnie strachu: autor $i$ dzieto a cenzura PRL, red. E. Skorupa, Kraków 2010, s. 115-131.

Tułać K., Niezależna polska prasa młodzieżowa lat 80. XX wieku. Gtosy o cenzurze, [w:] Zakazane i niewygodne. Ograniczanie wolności stowa w XIX $i$ XX wieku, red. D. Degen, G. Gzella, J. Gzella, Toruń 2015, s. 215-232.

Urgacz T., Aniol '87, Chrystus się rodzi, Baruch, Baltazar, Mongot, Dostojewski, Psy Dżeka, „Kultura” 1987, nr 51/52.

Urgacz T., Czarny opłatek, „Kultura i Życie” 1989, nr 17. 
Wojsław J., Miejsce cenzury w ocenach aparatu partyjnego w okresie politycznej konfrontacji lat 1980-1981, [w:] Nie należy dopuszczać do publikacji. Cenzura w PRL, red. G. Gzella, J. Gzella, Toruń 2013, s. 195-216.

Woźniak-Łabieniec M., Obecny nieobecny: krajowa recepcja Czesława Miłosza w krytyce literackiej lat pięćdziesiatych w świetle dokumentów cenzury, Łódź 2012.

Woźniakowski J., My i oni, rozm. T. Walas, „Dekada Literacka” 1996, nr 1.

Zakazane i niewygodne: ograniczanie wolności słowa od XIX do XXI wieku, red. D. Degen, G. Gzella, J. Gzella, Toruń 2015.

\section{Akty prawne}

Rozporzadzenie Prezesa Rady Ministrów z dnia 22 kwietnia 1975 r. w sprawie zakresu i trybu sprawowania nadzoru i kontroli przez Gtówny Urzad Kontroli Prasy, Publikacji $i$ Widowisk

Ustawa z dnia 31 lipca 1981 r. o kontroli publikacji i widowisk, Dz.U. nr 20 z 1981, poz. 99 .

\section{Materiały źródłowe}

AAN, GUKPPiW, sygn. 1304

AAN, GUKPPiW, sygn. 1545 (293/28)

AAN, GUKPPiW, sygn. 1684 (334/4),

AAN, GUKPPiW, sygn. 1686 (334/6)

AAN, GUKPPiW, sygn. 1704 (334/24),

AAN, GUKPPiW, sygn. 1769 (354/5)

AAN, GUKPPiW, sygn. 2014 (406/1)

AAN, GUKPPiW, sygn. 2060 (416/12)

\section{CENSORING OF RUSSIAN SUBJECTS IN POLISH POETRY OF THE 1980S}

\section{S U M M A R Y}

Key words: censorship; poetry; Main Office of Control of Press, Publications and Shows; Poland

The article discusses censoring Russian threads in polish literature of $80 \mathrm{~s}$ in XX century. The author based on the archival materials, found in The Archive of Modern Acts in Warsaw. He shows some examples of control: how poems of Jerzy Ficowski, Jan Lechoń, Jan Bolesław Ożóg and Tadeusz Urgacz were censored because of Russian threads. The article also contains information on legal conditions regarding the censorship of literature in Poland in the 1980s. 